\title{
Potencijalna toksičnost titanija
}

\section{Potential toxicity of titanium}

\author{
Lara Dežulović1, Gordana Čanadi Jurešićc ${ }^{*}$
}

\begin{abstract}
Sažetak. Titanij se široko primjenjuje zbog svoje biokompatibilnosti i dobrih biomehaničkih svojstava. Pokazuje dobru sposobnost vezanja za živo tkivo i kosti pa se često upotrebljava za zubne, ortopedske i srčane implantate. Upotrebljava se kao čisti titanij ili kao legura na bazi titanija, gdje dodatak drugog elementa titaniju omogućuje dobivanje boljih svojstava od samoga titanija. Unatoč inertnosti, titanij je i dalje podložan koroziji i otpuštanju štetnih metalnih iona u organizam. Većina studija pokazuje da je titanij izrazito biokompatibilan materijal, međutim određene studije ukazuju da materijali od titanija mogu postati nekompatibilni i prouzročiti štetne učinke. S obzirom na široku upotrebu titanija, javljaju se pitanja o mogućoj štetnosti titanija. Stoga je važno i dalje provoditi toksikološka ispitivanja, pomno procijeniti $i$ ispitati potencijalnu štetnost titanija te provjeriti potencijalne zdravstvene rizike za ljude i za ekosustav.
\end{abstract}

Ključne riječi: korozija; titanij; toksičnost; zubni implantati

\begin{abstract}
Titanium is widely used due to its biocompatibility and good biomechanical properties. Often it is the material of choice for making dental, orthopaedic and heart implants because it has good binding ability to living tissue and bones. It is used as pure titanium or as a titanium alloys, where the addition of another element or more of them allows to obtain better properties than titanium itself. Despite its inertness, titanium is still susceptible to corrosion and the release of harmful metal ions into the body. Most studies show that titanium is a highly biocompatible material, however there are certain studies that show that titanium materials can become incompatible and cause harmful effects. Given the widespread use of titanium, questions arise about its possible harmfulness. It is therefore important to continue to conduct toxicological tests, to carefully evaluate and examine the potential harmfulness of titanium, and to check for potential health risks to humans and the ecosystem.
\end{abstract}

Key words: corrosion; dental implant; titanium; toxicity
${ }^{1}$ Luka Rijeka d.d., Rijeka, Hrvatska

'Zavod za medicinsku kemiju, biokemiju i kliničku kemiju, Sveučilište u Rijeci, Medicinski fakultet, Rijeka, Hrvatska
*Dopisni autor:

Izv. prof. dr. sc. Gordana Čanadi Jurešić, dipl. ing. preh. teh.

Zavod za medicinsku kemiju, biokemiju i kliničku kemiju, Sveučilište u Rijeci, Medicinski fakultet, Braće Brancheta 20, 51000 Rijeka, Hrvatska

E-mail: gordanacj@medri.uniri.hr

http://hrcak.srce.hr/medicina 


\section{UVOD}

Element titanij otkrio je 1795. godine njemački kemičar Martin Heinrich Klaproth. Nazvao ga je prema grčkoj riječi titanos što znači „bijela zemlja”, "glina” ili „gips”, a u isto vrijeme označava Titane, bogove iz grčke mitologije, kao simbol snage ${ }^{1,2}$.

Titanij (Ti) je široko rasprostranjen kemijski element, atomskog je broja 22 i atomske mase 47,867 . Ubraja se u lake metale zbog relativne gustoće od $4506 \mathrm{~kg} / \mathrm{m}^{3}$. Nalazi se u kemijskoj sku-

Ovaj rad predstavlja pregledni članak o potencijalnoj toksičnosti titanija za ljudsko zdravlje. Rad pruža pregled literature osvrćući se posebno na istraživanja toksičnosti iona titanija oslobođenih iz materijala koji se koriste u izradi zubnih implantata. lako se smatra biokompatibilnim, u određenim su se studijama pokazali njegovi mogući negativni učinci na ljudsko zdravlje. pini prijelaznih metala. Deveti je element po zastupljenosti u zemljinoj kori. Srebrnaste je boje te ima poželjna fizikalna i mehanička svojstva, poput specifične visoke čvrstoće uz jako malu težinu odnosno gustoću, žilavost, otpornosti na kemikalije i postojanosti na zraku. Bitno je svojstvo i otpornost na koroziju koja nastaje uslijed visokog afiniteta prema kisiku i prema drugim elementima te u reakciji sa zrakom, kao mnogi drugi prijelazni metali stvara slojeve oksida na svojoj površini. Oksidacijska stanja koja može formirati jesu +4, +3 i +2, od kojih je najčešće +4 . Najvažniji oksid titanija je titanijev dioksid $\left(\mathrm{TiO}_{2}\right)$, tj. titanijev (IV) oksid koji ima molekulsku masu 79,9 g/mol, točku vrelišta $2972{ }^{\circ} \mathrm{C}$, talište $1843^{\circ} \mathrm{C}$ i relativnu gustoću od $4,26 \mathrm{~g} / \mathrm{cm}^{3}$ na $25^{\circ} \mathrm{C}$. Titanijev dioksid prah je bijele boje koji je slabo topljiv i ne gori ${ }^{3-5}$. Titanij se široko primjenjuje zbog svojih odličnih svojstava. Primjena mu je započela još u pedesetim godinama prošloga stoljeća: prvobitno se koristio u zrakoplovnoj industriji u kojoj se i danas najviše koristi. Vremenom je došlo do sve veće inženjerske i industrijske primjene. Danas se često koristi u kemijskoj, petrokemijskoj, energetskoj i arhitektonskoj industriji. Materijal je izbora za izradu svemirskih letjelica te se koristi u bojama, u kozmetičkim, farmaceutskim i prehrambenim proizvodima, u plastici, za izradu predmeta opće uporabe i sportske opreme, nakita, nalazi se u kremama za sunčanje i pastama za zube. Najčešće se koriste spojevi titanijevog dioksida $\left(\mathrm{TiO}_{2}\right) \mathrm{i}$ titanijevog klorida $\left(\mathrm{TiCl}_{4}\right)$. Budući da se titanij smatra inertnim materijalom pogodnim za bioimplantaciju, u novije se vrijeme sve više koristi u medicinskom i stomatološkom polju: za izradu protetskih implantata, umjetnih zglobova (kuk, koljeno), premosnica i dentalnih implantata ${ }^{1-3,6,7,9}$. S obzirom na široku upotrebu titanija, javljaju se pitanja o mogućoj štetnosti titanija i njegovim učincima na zdravlje. Stoga se pokušava pomno procijeniti i ispitati potencijalnu štetnost titanija te provjeriti potencijalne zdravstvene rizike za ljude i za ekosustav.

lako se smatra da je uporaba titanija sigurna, postoje izvješća o problemima uzrokovanim titanijem. Titanij je jedan od najčešće korištenih materijala za zubne implantate iako postoji povremeno odbacivanje implantata od titanija na mehaničkoj i na biološkoj razini. Provedene su određene studije o titaniju i njegovim legurama, kao i materijalima za površinsku obradu materijala kako bi se utvrdilo njihovo toksično djelovanje $^{3,4,6}$.

Ovaj rad predstavlja pregledni članak o potencijalnoj toksičnosti titanija za ljudsko zdravlje. Rad pruža pregled literature osvrćući se posebno na istraživanja toksičnosti metalnih iona titanija oslobođenih iz stomatoloških materijala koji se koriste u izradi zubnih implantata. Rad je nastao pretražujući pojmove "titanij”, „legure titanija”, „toksičnost”, „korozija”, „biokompatibilnost”, „zubni implantati” i različite kombinacije navedenih pojmova u tražilici PubMed za bazu podataka Medline.

\section{BIOKOMPATIBILNOST}

Biokompatibilnost ili bioprihvatljivost definira se kao sposobnost materijala da u dodiru sa živim tkivom ne izaziva oštećenje tkiva ili alergijske reakcije organizma. Ovo je svojstvo neophodno za osiguravanje sigurnog liječenja pacijenata. Materijali koji se ugrađuju u ljudsko tijelo nazivaju se biomaterijalima te moraju biti netoksični i inertni kako ne bi reagirali s okolnim tkivom ${ }^{10-12}$. 
Potrebno je naglasiti da se početna biokompatibilnost može promijeniti, a to se može dogoditi bilo uslijed korozije i zamora materijala tijekom određenog vremena ili uslijed promjene stanja pacijenta u vidu bolesti ili starenja.

Biomaterijali također moraju posjedovati dobra mehanička svojstva poput tvrdoće i čvrstoće, odnosno elastičnosti, plastičnosti, duktilnosti, rastezljivosti i žilavosti ${ }^{13}$. Metali i njihove legure već dugo privlače zanimanje znanstvenika kao dobar biomaterijal zbog njihove biofunkcionalnosti i integracije u tkiva te razvoja mikrostruktura ${ }^{14}$.

\section{Korozija i oslobađanje iona metala}

Korozija dolazi od latinske riječi corrodere što znači nagrizati i predstavlja elektrokemijski spontani proces koji se definira kao nenamjerno štetno trošenje materijala pod utjecajem okolišnih faktora, a taj nepoželjni proces dovodi do narušavanja svojstava materijala. Nastaje iz dviju simultanih reakcija: oksidacije i redukcije, tijekom kojih dolazi do gubitka metalnih iona. To znači da u tkivnim tekućinama na površini metala dolazi do korozije kao elektrokemijske redoks-reakcije, u kojoj se oksidacija, tj. gubitak elektrona iz metala, povezuje s redukcijom, tj. primanjem elektrona $u$ komponentama elektrolita. Taj se postupak korozije nastavlja sve dok se metal potpuno ne potroši, osim u slučaju pasivizacije, tj. stvaranja zaštitnog površinskog sloja. Stupanj potrošnje bilo kojeg metala ovisi o kemiji otapala u koje je uronjen $^{15,16}$.

Prema obliku i mjestu razaranja materijala postoje razne vrste korozija: opća, lokalna, selektivna i interkristalna. Opća korozija može ravnomjerno ili neravnomjerno zahvatiti cijelu površinu metala. Kod lokalne korozije razlikujemo pjegastu koja se javlja na većim dijelovima metalne površine i točkastu (jamičastu, engl. pitting) koja stvara udubine na usko lokaliziranim žarištima kružnog presjeka, a može se proširiti i ispod metalne površine. Lokalna se korozija može javiti i u kontaktu dvaju elemenata u elektrolitu, pa tako razlikujemo galvansku kontaktnu koroziju nastalu kada su različiti metali u kontaktu od pukotinske kontaktne korozije nastale kada su dva ista metala $u$ kontaktu. Postoji i interkristalna (intergranularna) korozija koja se širi u dubinu. Često se istodobno pojavljuju različiti oblici korozije. Moguće je zaštititi materijale i usporiti koroziju elektrokemijskim postupcima i premazivanjem metala antikorozijskom zaštitnom oksidnom prevlakom ${ }^{13,15}$.

Određeni mikroorganizmi mogu apsorbirati i metabolizirati metal iz legura, pa je moguća i korozija nastala pod mikrobiološkim utjecajem. Također, metabolički nusproizvodi mikroorganizama mogu dovesti do povoljnih uvjeta u usnoj šupljini za stvaranje korozije (npr. niži pH) ${ }^{15}$.

Metali i metaloidi mogu štetno djelovati na biološke sustave ako su otrovni ili im se poveća količina iznad određene vrijednosti. Zbog toga svaki organizam ima sustave za izbjegavanje toksičnosti i stjecanje tolerancije kako bi osigurao staničnu zaštitu od esencijalnih metala potrebnih za razne biokemijske aktivnosti. Ukoliko je sustav detoksikacije neispravan mogu nastati brojne bolesti i poremećaji. Toksičnost određenog metala ovisi o njegovim fizikalno-kemijskim svojstvima, oksidacijskom stanju i mehanizmu njegove apsorpcije te o unutarstaničnoj raspodjeli, interakciji s raznim molekulama i svojstvu da stvara ligande ${ }^{17}$.

Toksični metal može imati razne štetne učinke: zbog sposobnosti vezanja na proteine može inhibirati funkcije enzima, poremetiti funkciju proteina odgovornih za regulaciju i napredovanje staničnog ciklusa te dovesti do apoptoze. Metali mogu biti citotoksični i genotoksični. Citotoksičnost je svojstvo metala da razara stanice, utječe na njihov rast i stanični ciklus. Toksičnost metala dovodi do oksidativnog stresa stvaranjem toksičnih razina slobodnih radikala, tj. vrlo reaktivnih kisikovih vrsta (engl. Reactive Oxygen Species; ROS) iz molekularnog kisika. ROS sadrži nesparene elektrone i nastoji se spojiti u stabilne elektronske veze pa tako narušava stabilnost drugih molekula i oštećuje ih pokrećući lančanu reakciju oksidacije proteina, peroksidacije lipida i oštećenja DNA. Većina metala i metaloida slabi su mutageni i ne oštećuju izravno DNA, stoga se genotoksičnost očituje $u$ ometanju procesa popravljanja DNA. Metali mogu štetno djelovati i na razne druge načine, primjerice ometanjem propusnosti membrane, pogrešnim prevođenjem mRNA i nepravilnim smatanjem proteina ${ }^{17,18}$. Usna je šupljina vlažan medij u kojem se zbivaju mnogi biokemijski i mikrobiološki procesi te su 
prisutne brze promjene temperature i pH vrijednosti te blago bazična slina, a može se pojaviti i jako kisela regurgitirana želučana tekućina te abrazija zbog konzumiranja određene vrste hrane ${ }^{10,13}$. Poznato je da može doći do bioloških reakcija uslijed oslobađanja iona metala u usnu šupljinu iz stomatoloških materijala tijekom kratkotrajnog ili dugotrajnog perioda ${ }^{11,18}$. Za procjenu lokalnih i sistemskih učinaka važno je znanje o otpuštanju različitih elemenata iz stomatoloških materijala u usnu šupljinu ${ }^{19}$.

Štetne učinke zbog zubnih metalnih materijala uglavnom uzrokuje korozija, što rezultira oslobađanjem metalnih iona i naknadnim interakcijama metal-protein ili metal-stanica. Parametri potrebni za oslobođenje metalnih iona jesu: vrsta legure, vrsta korozije, sastav i kemijske karakteristike korozivne otopine poput sline, koja pridonosi koroziji zbog fluktuacije $\mathrm{pH}$ vrijednosti i temperature, enzimske i mikrobne aktivnosti te raznih tvari unesenih u usnu šupljinu hranom i pićem ${ }^{20}$.

Li i sur. proveli su istraživanje stupnja citotoksičnosti legure titanija koja sadrži Mo, Nb i Si, proizvedene metalurgijom praha. Usporedili su leguru u kompaktnom, čvrstom obliku (engl. bulk) s legurom u praškastom obliku, tzv. metalni prah (engl. powder). Citotoksičnost su testirali na $\mathrm{SaOS}_{2}$ stanicama sličnim osteoblastima. Rezultati su pokazali značajno manji stupanj citotoksičnosti u kompaktnom obliku nego u praškastom obliku, zbog znatno niže otpuštene koncentracije metalnih iona u podlogu. Utvrdili su da ioni $\mathrm{Ti}, \mathrm{Nb}, \mathrm{Mo}$ i Si otpušteni iz praškastog oblika dovode do značajne citotoksičnosti. Prema ispitivanju je također ustanovljeno da bi sadržaj Mo trebalo ograničiti u Ti legurama jer je pokazao značajnu citotoksičnost, čak i u kompaktnom obliku ${ }^{21}$.

Uloga vremena bitna je za procjenu otpuštanja metalnih iona jer što je vrijeme izlaganja vlažnom oralnom okruženju duže, materijali imaju veću tendenciju korodirati i oslobađati metalne ione u usnu šupljinu. Oslobađanje metalnih iona može se ubrzati u slučaju galvanske korozije - npr. ako su žica i nosači ortodontskih naprava izrađeni od dviju različitih legura lemljeni zajedno, trenje između žica i nosača ortodontskih naprava pridonosi procesu korozije. Metalni ioni nisu biorazgradivi i njihovo produljeno oslobađanje može dovesti do akumulacije u tkivima te imati toksične lokalne i sistemske učinke ${ }^{22}$. Određeni metali mogu se akumulirati u ljudska tkiva nakon gutanja sline i resorpcije u gastrointestinalnom traktu, nakon difuzije putem membrane u oralnoj sluznici ili nakon migracije na pulpu kroz dentinske tubule ${ }^{19}$.

Biokoroziju titanijevih proteza istražili su D. Cadosch i sur. s pretpostavkom da ljudske koštane stanice mogu izazvati nagrizanje metala i oslobađanje metalnih iona. Pokazalo se da kulture osteoklasta na površini titanija mogu lučenjem vodikovih iona, tj. protona, stvoriti okruženje prikladno za koroziju jer na taj način dolazi do sekrecije $\mathrm{HCl}$ i snižavanja $\mathrm{pH}$ te do destabilizacije zaštitnog oksidnog sloja i nagrizanja metalne površine. Titanijevi ioni mogu se vezati za citoplazmatske i nuklearne stanične strukture te stvoriti stabilne komplekse koji ostaju u osteoklastima. S obzirom na snažan afinitet iona titanija za fosforiliranu staničnu strukturu i vezanja za membranske fosfolipide dolazi do ometanja enzimskih i signalnih putova stanice, poremećenih staničnih funkcija i apoptoze. Nakon stanične smrti moguće je otpuštanje kompleksa titanij-proteina u izvanstanični prostor i ulazak u sistemsku cirkulaciju te izazivanje upalne imunološke reakcije. Oslobađanje titanijevih iona može potaknuti stvaranje osteolitičkih lezija u periprotetičkoj kosti, pridonoseći popuštanju implantata ${ }^{16}$.

\section{ISPITIVANJA TOKSIČNOSTI}

Utvrđivanje biokompatibilnosti, funkcionalnosti i sigurnosti materijala za implantaciju u ljudsko tijelo provodi se složenim postupcima ispitivanja. Potrebno je prvo provesti ispitivanja o akutnoj toksičnosti, citotoksičnosti, genotoksičnosti i supkroničnoj toksičnosti, a zatim ispitati kroničnu toksičnost, karcinogenost i reproduktivnu toksičnost. Biološka istraživanja koja se provode uključuju ispitivanja fizikalnih i mehaničkih svojstava materijala te ispitivanja procjene rizika moguće štete i nastalog učinka. Ispitivanja se izvode: testovima in vitro na kultiviranim stanicama $u$ umjetno stvorenom okruženju, testovima in vivo koji se izvode na životinjama i testovima u kliničkim ispitivanjima. Testiranja moraju biti standardizirana i ponovljiva ${ }^{13,15,19,23}$. 
Ispitivanje biokompatibilnosti materijala u kliničkim ispitivanjima predstavlja izazov i otežano je jer je prirodno okruženje podložno stalnim i naglim promjenama temperature, $\mathrm{pH}$ vrijednosti i samog sastava. Temiz i sur. proveli su kliničko ispitivanje otpuštanja iona titanija iz zubnih implantata i posljedične razine titanija u krvi. Obuhvatili su 30 pacijenata (15 žena i 15 muškaraca) kojima su izvadili krv prije i nakon implementiranja zubnih implantata. Dobiveni rezultati nisu ukazali na značajan porast titanija u krvi. Jedina značajna razlika koju su ustanovili bila je veća razina titanija u krvi kod žena u odnosu na muškarce. Istražitelji su to povezali s prisustvom titanijevog dioksida $u$ kozmetičkim, farmaceutskim i prehrambenim proizvodima, koje su žene više koristile od muškaraca ${ }^{24}$.

Kod kliničkih ispitivanja treba voditi računa o biološkim varijacijama koje su specifične za svakog pacijenta jer to može utjecati na standardiziranje studije. Hafez i sur. proveli su longitudinalno kliničko ispitivanje citotoksičnosti i genotoksičnosti vijaka i žica koje čine fiksne ortodontske naprave. Istraživanje su proveli na stanicama bukalne sluznice, uspoređujući pacijente s kontrolnom skupinom tijekom razdoblja od šest mjeseci. Rezultati su ukazali na značajan porast iona metala u stanicama pacijenata, što je dovelo do smanjenja održivosti stanica i oštećenja DNA. Metalni ioni interferiraju s mnogim zaštitnim i reparativnim putovima koji održavaju staničnu homeostazu i integritet DNA. Različite kombinacije metala iz kojih su sastavljeni vijci i žice dovele su do različitih učinaka. Kombinacija vijaka od titanija sa žicama od nikla i žicama od titanija pokazala je citotoksičnost i genotoksičnost. Usprkos biokompatibilnosti titanija došlo je do bioloških promjena kada su se vijci od titanija kombinirali sa žicama od različitih elemenata ${ }^{25}$.

U studijama in vivo stomatološki materijali proučavani su kod pasa, majmuna i svinja. lako se specifična anatomija ovih vrsta prilično razlikuje od ljudske, reakcije tkiva prilično su slične ${ }^{23}$. Studije in vivo korisne su u objašnjavanju kako se ortodontski materijali ponašaju u svom stvarnom okruženju, ali je interpretacija rezultata otežana zbog mnogih čimbenika koji nisu pod eksperimentalnom kontrolom ${ }^{25}$.
Modeli staničnih kultura in vitro mogu se koristiti u preliminarnoj procjeni biokompatibilnosti materijala, odnosno za testiranje citotoksičnosti i genotoksičnosti. Ovakva su se ispitivanja pokazala vrlo korisnima u proučavanju staničnih funkcija. Zbog relativne jednostavnosti pružaju lakši pristup u istraživanju jer se koristi umjetno okruženje koje ima ipak viši stupanj stabilnosti nego prirodno okruženje. Koroziji metala pridonose brojni biološki čimbenici poput sastava sline i prisutnosti mikroorganizama te konzumacije kisele hrane i pića. Habanje je još jedan važan čimbenik koji može ubrzati korozivne procese. Rezultati dobiveni $u$ ispitivanjima in vitro ne odražavaju nužno kliničke uvjete, stoga in treba ispravno tumačiti i točno ekstrapolirati te in smatrati isključivo indikativnima. Važno je usporediti in s rezultatima dobivenim $u$ kliničkim ispitivanjima, zato valja provoditi ispitivanja istovremeno u uvjetima in vitro i u kliničkim uvjetima. To bi se pokazalo prilično korisnim ukoliko bi se otkrio specifičan biološki odgovor tijekom kliničkog testiranja kojeg bi trebalo dodatno i pomnije istražiti ${ }^{13,19,20,23}$.

Postoje razni modelni organizmi koji se koriste za provođenje istraživanja o biološkim procesima koji se zbivaju u višim živim bićima, prevladavajući tako eksperimentalna i etička ograničenja u in vivo i u kliničkim ispitivanjima. Karathia i sur. usporedili su biološke procese u različitim organizmima koristeći biološke ortologe gena kako bi utvrdili hoće li dva organizma biti međusobno usporediva, odnosno može li određeni modelni organizam biti prikladan za korištenje u proučavanju viših organizama. Usporedili su kvasac S. cerevisiae sa 704 druga organizma. Razmatrajući ovaj jednostanični eukariotski mikroorganizam, njegove proteine i sličnost s organizmom kojeg se želi proučavati, može se zaključiti da je kvasac idealan modelni organizam ${ }^{26}$. Zbog toga je pupajući kvasac jako bitan za znanost jer je pridonio razumijevanju osnovne biologije eukariota te je najjednostavniji model za proučavanje odnosa genotipa i fenotipa u eukariotskim stanicama. Ima brojnih prednosti: relativno je jeftin, lako se uzgaja te u kratkom vremenskom periodu može pružiti veliku količinu podataka. Eksperimente na genomu koji su izvedivi s kvascem, mnogo je teže izvoditi s ostalim modelnim organizmima ${ }^{18,27-29}$. 
Njegova stanična struktura i funkcionalna organizacija ima mnogo sličnosti sa stanicama organizama viših razina ${ }^{11,30,31}$. Velika količina gena (30 - $45 \%)$ koji su uključeni u ljudske bolesti ima ortologe kvasca, odnosno funkcionalne homologe $^{12,22,30,32}$. Yang i Pon proveli su istraživanje o učincima iona metala otpuštenih iz zubnih legura na rast stanica i na funkciju respiratorne aktivnosti mitohondrija kvasca. Budući da je većina toksičnih metalnih iona sposobna izazvati oksidativni stres na stanicama kroz mitohondrijski respirator-

U usnoj su šupljini ortodontski aparati izloženi kemijskim, biološkim i fizičkim agensima koji mogu prouzročiti koroziju i dovesti do oksidacije njihovih metalnih komponenata, otpuštanja metalnih iona $u$ medij te poremećaja stanične oksidoredukcijske ravnoteže.

ni lanac, mitohondriji mogu pridonijeti i biti ciljna meta toksičnosti metala. Dobiveni su rezultati ukazali da su toksični učinci iona metala na rast stanica kvasca slični kao i za stanice sisavaca, a korelira i rangiranje toksičnosti $(\mathrm{Hg})>(\mathrm{Ag})>(\mathrm{Au})>$ $(\mathrm{Cu}, \mathrm{Co}, \mathrm{Ni}, \mathrm{Zn})$ na rast stanica ${ }^{18}$. Također, transportni mehanizmi kvasca ključni su za stvaranje i održavanje gradijenata protona i kationa kroz stanične membrane i igraju važnu ulogu u istraživanjima o prijenosu metalnih iona u stanice. Postojanje mnoštva mehanizama za prijenos, korištenje specifičnih supstrata i različitih načina regulacije u samo jednoj stanici opravdava ulogu kvasca kao modelnog sustava za membranski transport u eukariotskim stanicama viših organizama ${ }^{29}$.Mnoštvo je bioloških procesa koji se mogu proučavati u kvascu: oksidativni stres i starenje stanica, izučavanje i smatanje proteina, prenošenje signala, interakcije protein-protein, genske funkcije i njihova interakcija, regulacija ekspresije gena, stanični ciklus, metabolizam stanica, apoptoza $26-28,30$. Budući da kvasac dijeli biokemijske i genetske sličnosti s višim organizmima, to omogućuje istraživanje mnogih znanstvenih pitanja od kliničkog interesa, uključujući i izučavanje neurodegenerativnih bolesti gdje se pokazao kao jako prikladan model u provedbi istraživanja na mitohondrijima ${ }^{12,33,34}$.
Kvasac se pokazao izvrsnim modelom u istraživanju aspekata biologije metala, učinaka nastalih djelovanjem metala, procesa tolerancije i detoksikacije te djelovanja regulatornih mehanizama. $\mathrm{U}$ stjecanju tolerancije na metal uključuje se širok spektar bazalnih staničnih funkcija. Postoji mogućnost da metali na neki način aktiviraju transkripcijske faktore i signalne proteine te na taj način uđu u stanicu, što još nije u potpunosti razjašnjeno ${ }^{17}$.

Procjene citotoksičnosti metala uglavnom se najprije provode testiranjem oslobađanja metalnih iona iz materijala uronjenih u otopinu pri neutralnom $\mathrm{pH}$ zbog kompatibilnosti s fiziološkim uvjetima. Nakon toga ispituju se učinci na stanice tih iona oslobođenih u medij. lako se uglavnom za procjenu citotoksičnog učinka stomatoloških materijala koriste kultivirane stanične linije poput fibroblasta i osteoblasta ${ }^{20}$, i kvasac se pokazao dobrim modelnim organizmom za tu vrstu istraživanja $^{11,12}$.

\section{STOMATOLOŠKI MATERIJALI}

Usna šupljina predstavlja izazovan medij zbog biokemijskih uvjeta poput vlažnosti, brzih promjena temperature i $\mathrm{pH}$, abrazije nastale od određene hrane, djelovanja blago bazične sline i jako kisele regurgitirane želučane tekućine te zbog mikrobioloških uvjeta prisutnih u ustima ${ }^{10,13}$. Ortodontske naprave izrađuju se od različitih dijelova koji se spajaju zavarivanjem ili lemljenjem. Materijali za njihovu izradu moraju posjedovati određena fizikalna i mehanička svojstva, a izrađeni su od metalnih legura poput nehrđajućeg čelika, nikal-titanija, čistog titanija, kobalt-kroma ${ }^{22}$. U usnoj šupljini ortodontske su naprave izložene kemijskim, biološkim i fizičkim agensima koji mogu prouzročiti koroziju i dovesti do oksidacije njihovih metalnih komponenata te poremećene stanične oksidacijsko-redukcijske ravnoteže ${ }^{35}$. Mogu se pojaviti lokalne ili sistemske reakcije preosjetljivosti i alergije. Otpušteni metalni ioni mogu se lokalno i sistemski raspodijeliti i imati ulogu u etiologiji oralnih i sistemskih patoloških stanja. Toksične učinke može prouzročiti živa iz zubnih amalgama te elementi iz raznih legura kao što su bakar, kositar, zlato, paladij, kobalt i krom, a nikal predstavlja čest alergen ${ }^{10,19,20}$. 
Kako bi se izbjeglo štetno djelovanje, citotoksičnost, genotoksičnost i reakcija preosjetljivosti, pokušava se pronaći što bolji materijal za izradu stomatoloških materijala koji bi bio inertan, stabilan i trajan, da što manje reagira s vlažnim okolišem u usnoj šupljini te da nije štetan. Stomatološki materijali moraju posjedovati svojstva prirodnih tkiva koja se zamjenjuju ${ }^{10,13}$.

Švedski znanstvenik Branemark je 1960-ih godina definirao oseointegraciju, učvršćivanje umjetnog korijena u kost pacijenta i tako doveo do razvoja prvih implantata. Zubni se implantati primjenjuju za nadomještanje izgubljene prirodne trajne denticije kako bi se povratila funkcija žvakanja i pridonijelo estetici ${ }^{9,36}$. Važno je postići pravilnu funkciju implantata tako da mogu održavati dinamička i statička opterećenja kojima su izloženi, a također implantati moraju biti takvi da je vrijeme zacjeljivanja što kraće, moraju imati nisku mogućnost pojave kvarova i minimalnu nelagodu za pacijente prilikom ugradnje i u fazi zacjeljivanja te ne smiju biti štetni ${ }^{5}$. U studijama o biološkim i mehaničkim aspektima implantacijskih sustava izvještava se da alergijski odgovor na materijale može dovesti do zatajenja implantata. „Kvar” implantata može također nastati i zbog loše oralne higijene te taloženja plaka i kamenca oko implantata ${ }^{6}$.

Postoje studije o biokompatibilnosti materijala ortodontskih naprava u kojima se analiziralo oslobađanje metalnih iona u umjetnu slinu pri niskim ili neutralnim pH-vrijednostima. Kako su u osnovi svi metali koji izgrađuju ortodontske sustave prijelazni metali (željezo, krom, kobalt, molibden, nikal i titanij), oni stvarajući velike količine ROS-a, mogu dovesti do oksidacijskog stresa koji narušava staničnu redoks-homeostazu i posljedično oštećuje biomolekule (lipide, proteine i DNA) ${ }^{22}$. $U$ današnje vrijeme titanij je jedan od najčešće korištenih materijala za zubne implantate, a niska gustoća titanija omogućuje stvaranje laganih proteza velike čvrstoće. Odljevci od titanija obično se koriste za izradu krunica, okvira mostova i cijelih ili djelomičnih okvira proteza te zubnih implantata $^{9}$. Može se koristiti kao komercijalno čisti titanij i kao titanijeva legura. Komercijalno čisti titanij ima čvrstoću jednaku jačini nehrđajućeg čelika s upola manjom gustoćom. Posjeduje najveću for- mabilnost i izvrsnu otpornost na koroziju i visoku temperaturu. Legure na bazi titanija nastaju dodavanjem drugih elemenata čistom titaniju kako bi mu se poboljšala svojstva. Obično se dodaju: aluminij, berilij, kadmij, kobalt, krom, bakar, željezo, mangan, molibden, nikal, paladij i vanadij². Uglavnom vlada mišljenje da je titanij, zbog svojih fizikalnih i kemijskih svojstava, jedan od biološki najkompatibilnijih metalnih materijala za izradu zubnih implantata ${ }^{9}$. Zaštita od korozije nastaje zbog sposobnosti da na svojoj površini tvori stabilan, kompaktan i netopiv zaštitni oksidni sloj $^{10}$. Može stvoriti nekoliko oksidnih konfiguracija (TiO, $\mathrm{TiO}_{2} \mathrm{i} \mathrm{Ti}_{2} \mathrm{O}_{5}$ ), od kojih je titanijev dioksid $\left(\mathrm{TiO}_{2}\right)$ najstabilniji i najčešće nastali oksid. lako površinski zaštitni sloj dovodi do pasivizacije, često nije trajan jer je osjetljiv na mehaničke i na kemijske podražaje, pri čemu korozijska otpornost opada. U fluoriranom i kiselom okruženju povećava se osjetljivost na koroziju i to dovodi do probijanja visoko zaštitnog titanij-oksidnog sloja. Prehrana bogata natrijevim kloridom i kiselim gaziranim pićima te paste za zube i vode za ispiranje usta koje sadrže fluor pridonose koroziji ${ }^{15}$.

lako se titanij smatra veoma poželjnim materijalom, povremeno može doći do problema na mehaničkoj i na biološkoj razini. Mehanički problemi nastaju zbog razgradnje materijala u samom implantatu, a biološki se problemi mogu pojaviti zbog oslobađanja iona iz implantacijskog sustava ${ }^{6}$.

\section{POTENCIJALNA TOKSIČNOST TITANIJA}

Uz biokompatibilnost, titanij posjeduje i dobra biomehanička svojstva, odnosno ima dobru sposobnost vezanja za živo tkivo i kost ${ }^{10}$. Trenutno se za medicinske i stomatološke materijale koriste najviše komercijalno čisti titanij te legure plemenitih metala na bazi titanija i legure neplemenitih metala na bazi titanija ${ }^{2,20}$. Najčešće korištena legura na bazi titanija je titanij-aluminij-vanadij legura (Ti-6Al-4V), a često se koriste i nikal-titanij (Ni-Ti) i titanij-molibden (Ti-Mo) legure ${ }^{1,6}$. U novije vrijeme dobra mehanička svojstva pokazuju i legure na bazi titanija bez vanadija (Ti-6Al-7N i Ti-5Al-3Mo-4Zr). Stvaranje legura dodatkom određenog elementa titaniju omogućuje manipuliranje njegovim svojstvima radi dobivanja optimalnih svojstava². 
lako su titanij i njegove legure pokazali veliku otpornost na koroziju, i dalje je ona moguća uslijed bioloških i elektrokemijskih procesa u usnoj šupljini ${ }^{6}$. Generalno vlada mišljenje da titanij nema toksičnih učinaka na humane fibroblaste i da ne dovodi do upalnog odgovora u tkivima oko ugrađenog titanija7. Stupanj korozije za titanij znatno je manji od maksimalno prihvaćene brzine korozije za primjenu biomaterijala: $<0,02 \mathrm{~mm} / \mathrm{g}$ u usporedbi s $0,13 \mathrm{~mm} / \mathrm{g}^{2}$. Međutim, zabilježeno je da materijali od titanija mogu postati nekompatibilni i prouzročiti štetne učinke ${ }^{37,38}$. Znanje o fizikalno-kemijskom stanju elemenata oslobođenih uslijed korozije od velike je važnosti za toksikološku procjenu legura.

Lee i sur. istražili su učinak iona metala oslobođenih elektrokemijskom galvanskom korozijom na mišje fibroblaste L-929. lako nisu ispitivali cjelokupno intraoralno okruženje, slinu i mikroorganizme, došli su do zaključka da ukoliko su Ni-Cr legure bile u kontaktu s titanijem, dolazi do smanjenog staničnog rasta, zato što galvanska korozija dovodi do bržeg oslobađanja iona metala (Ni, $\mathrm{Cr}$, Mo, Be i Ti), izazivanja citotoksičnost i fizioloških nuspojava na tkivu ${ }^{39}$.

Ortiz i sur. u svom su istraživanju testirali tri vrste iscrpina metala i pratili njihov utjecaj na vijabilnost $i$ oštećenje DNA na stanicama humanih fibroblasta 142BR. Iscrpine su pripremili iz ortodontskih nosača i bravica izrađenih od triju vrsta materijala, odnosno od nehrđajućeg čelika, titanija (sastava: $99 \%$ Ti i $1 \% \mathrm{Cr}$ ) i legure na bazi titanija bez nikla s tragovima C, Si, Mn, Cr, Mo. Nakon 30 dana u svakoj su iscrpini odredili udio i vrstu metalnih iona koji su se otpustili te su utvrdili da su količine i vrste metalnih iona bile različite od deklariranih (početnih). Iscrpina od nehrđajućeg čelika pokazala je najveću toksičnost, dok iscrpina od titanija nije imala toksičan učinak na fibroblaste. Iscrpine s titanijem pokazale su gotovo 1,5 puta veću vijabilnost od kontrolnih medija bez metalnih iona te genotoksičnost jednaku kontrolnoj skupini. Na temelju toga istraživači smatraju da kod materijala presvučenih titanijem dolazi i do manje korozije, a zbog veće vijabilnosti i do hormeze - povoljnog biološkog odgovora na malu izloženost toksinima i drugim stresorima ${ }^{36}$.

Špalj i sur. ispitali su šest vrsta ortodontskih žica: od nehrđajućeg čelika, Ni-Ti i Cu-Ni-Ti žica, Ni-Ti žica presvučenih rodijem te $\mathrm{Co}-\mathrm{Cr}$ i Ti-Mo žica. Umjetna slina u koju su bile uronjene žice igrala je aktivnu ulogu zbog pojave korozije i pasivnu ulogu zbog transporta oslobođenih iona metala do stanica. Toksičnost otpuštenih metalnih iona ispitivali su na staničnim kulturama fibroblasta miša L-929. Ispitivane žice ne izazivaju akutnu toksičnost, ali zato stvaraju slobodne radikale i tako dovode do oksidacijskog stresa. Standardne $\mathrm{Ni}$-Ti žice stvaraju najvišu razinu oksidacijskog stresa i tako pokazuju najmanju biokompatibilnost. Oksidacijski stres vrlo vjerojatno nastaje zbog iona $\mathrm{Ni}$ jer je prisutan u visokom omjeru u navedenim žicama (50-60 \%). Nešto nižu razinu oksidacijskog stresa stvaraju žice Ni-Ti presvučene rodijem, Cu-Ni-Ti i Co-Cr, dok žice Ti-Mo dovode do najmanjeg stvaranja oksidacijskog stresa. Sve ispitivane žice koje sadrže $\mathrm{Ni}$, pokazuju tendenciju stvaranja oksidacijskog stresa. U Ni-Ti žicama presvučenim rodijem prevlaka rodija djeluje kao zaštita i usporava koroziju te stvaranje oksidacijskog stresa. U Cu-Ni-Ti žicama nizak udio $\mathrm{Ni}$ razlog je manjeg izazvanog stresa. Najmanji oksidacijski stres i inhibiciju rasta stanica pokazale su Ti-Mo žice, ali je došlo do niže održivosti stanica, što bi moglo biti posljedica prisutnosti molibdena ${ }^{35}$. Prema ovom istraživanju, titanij se ne smatra toksičnim nego je toksičnost nastala kao rezultat prisutnosti drugih elemenata u legurama.

Yonekura i sur. proveli su slično istraživanje. Ispitivali su stabilnost ortodontskih $\mathrm{Ni}-\mathrm{Ti}$ žica, $\beta-\mathrm{Ti}$ (Ti-Mo-Zr) žica, Co-Cr-Ni žica i žica od nehrđajućeg čelika te njihovu osjetljivost na koroziju nakon uranjanja u 0,9-postotnu otopinu $\mathrm{NaCl}$. Količinu oslobođenih iona metala odredili su atomskom apsorpcijskom spektrofotometrijom. Iz Ni-Ti žica i Ti-Mo-Zr oslobodile su se male količine iona $\mathrm{Ni} i$ Mo, dok su količine oslobođenih iona Ti bile ispod granice detekcije. Otpornost na koroziju bila je veća kod žica od legura titanija jer je ukupna količina oslobođenih iona metala iz tih žica bila izrazito mala. Uspoređujući testirane žice, Ti-Mo-Zr žica pokazala se najprikladnijom zbog najveće otpornosti na opću i lokaliziranu koroziju ${ }^{40}$.

lako je otpuštanje iona metala smanjeno zbog površinskog oksidnog sloja, u slučaju njegovog uklanjanja došlo bi do povećanja brzine korozije 
te posljedično veće količine oslobođenih iona metala. To može nastati, primjerice, prilikom abrazije ili prilikom ogrebotina nastalih na površini ortodontskih žica zbog njihovog savijanja ili djelovanja sila ${ }^{40}$. Također, niska $\mathrm{pH}$ vrijednost nastala uslijed zubnog plaka formiranog od bakterija može prouzročiti pucanje zaštitnog sloja i ubrzavanje procesa korozije ${ }^{41}$. Jednom kad se zaštitni sloj poremeti ili odvoji od dijela površine, titanij može korodirati jednako kao i drugi metali ${ }^{36}$. Ortodontski miniimplantati moraju podnijeti velika opterećenja tijekom postavljanja, što može rezultirati lomovima. Čistom se titaniju, stoga, dodaju elementi koji će mu poboljšati svojstva i pojačati čvrstoću. Legura Ti-6Al-4V ima veću čvrstoću i otpornost od čistog titanija, te formirani oksidni sloj na površini legure osigurava otpornost na habanje i koroziju. Međutim, kada se legura ugradi u ljudsko tijelo, mogu se dogoditi promjene u zaštitnom sloju djelovanjem tjelesnih tekućina, prisutnosti različitih aminokiselina i proteina, visoke koncentracije kloridnih iona i niske koncentracije otopljenog kisika te niže pH vrijednosti. Otpušteni metalni ioni mogu se akumulirati u lokalna i udaljena tkiva i dovesti do nuspojava u ljudskom tijelu. Na toj su tematici radili de Morais i sur. koji su istraživali akumulaciju metalnih iona u tkivima bubrega, jetre i pluća kunića nakon različite vremenske izloženosti. Testirali su ortodontske implantate izrađene od legure Ti-6Al-4V postavljajući in u tibiju kunića. Koristili su kuniće kao životinjski model zbog dobre korelacije između zečje i ljudske fiziologije, iako treba pretpostaviti da su praćeni vremenski periodi od 1, 4 i 12 tjedana za kuniće otprilike 3, 12 i 36 tjedana za ljude i treba uzeti u obzir razlike u omjerima dimenzije implantata i mase tijela životinje odnosno ljudi. Primijetili su otpuštanje iona Ti, Al, V i njihovo nakupljanje u tkivima. Ti i V dosegnuli su najviše vrijednosti nakon četiri tjedna, dok se Al konstantno otpuštao u svim vremenskim intervalima. Međutim, nijedna vrijednost metalnih iona nakupljenih u tkivima kunića nije dosegla toksične koncentracije ${ }^{42}$.

Legura Ti-6Al-4V često se koristi za izradu ortodontskih minivijaka. Ta legura stvara površinski oksidni sloj od $\mathrm{TiO}_{2} \mathrm{~s}$ malim primjesama $\mathrm{Al}_{2} \mathrm{O}_{3}$. Složenom procesu korozije u usnoj šupljini može pogodovati i prisutnost određenih kemikalija poput otopina na bazi natrijevog flourida, gdje visoke koncentracije fluorida pospješuju koroziju ${ }^{6}$ jer umanjuju otpornost titanija na koroziju ${ }^{43}$. Da bi to ispitali, Blaya i sur. ortodontske su minivijke izrađene od Ti-6Al-4V legura izlagali fluoridima $u$ oralnom okolišu. Koristili su pokuse preživljavanja kako bi utvrdili citotoksičnost. To su proveli na dva načina: izravnim izlaganjem stanica kvasca $S$. cerevisiae minivijcima u tekućem mediju i neizravnim izlaganjem ionima metala koji su se oslobodili u komercijalnoj umjetnoj slini. Zaključili su da se iz minivijaka u prisutnosti fluoridnih iona ne otpuštaju značajne količine metalnih iona niti one pokazuju citotoksičan učinak ${ }^{31}$. Utjecaj $\mathrm{pH}$ vrijednosti na koroziju ispitali su Koike i Fujii testirajući otpornost čistog titanija u organskim kiselinama: mravljoj i mliječnoj kiselini. Pokazali su da niske $\mathrm{pH}$ vrijednosti pogoduju otpuštanju iona titanija. Uspoređujući rezultate otpuštanja iona titanija u mravljoj i mliječnoj kiselini, došli su do zaključka da je korozija aktivnija u mravljoj nego u mliječnoj kiselini pri istoj koncentraciji kiseline, što znači da korozivna svojstva titanija izrazito ovise o $\mathrm{pH}^{44}$.

Prema istraživanju Reigose i sur. o štetnosti zubnih implantata od titanija nije nastupio toksičan učinak na štakorske stanične linije. Ispitali su tri različita komercijalno dostupna zubna implantata od titanija: ASTM titanij (površina urezana kiselinom), Nobel (anodno oksidirana površina) i 3i titanij (pjeskarena površina). Medij koji su koristili za kulturu stanica bio je sličan oralnom okruženju. Korozijom na metalnoj površini potaknulo se oslobađanje iona titanija, međutim takvo oslobađanje nije utjecalo na održivost stanica. Također, rezultati Comet testa pokazali su da niti jedna vrsta proučavanih zubnih implantata od titanija nije izazvala genotoksičnost ${ }^{45}$.

$\mathrm{Ni}$-Ti legura često se koristi za izradu implantata, proteza, krunica, vijaka, žica i nosača. Postoje studije koje daju različite rezultate o toksičnim učincima navedenih materijala. Dinca i sur. istraživali su citotoksičnost legure $\mathrm{Ni}$-Ti testovima in vitro koristeći stanične kulture mikroorganizama kvasca S. cerevisiae i bakterija E. coli. Mjerili su koncentraciju otpuštenih iona metala $u$ otopinu $i$ zatim proučili rast staničnih kultura. Nisu utvrdili 
citotoksičan učinak te su zaključili da su Ni-Ti legure prikladne za upotrebu u stomatološkim i medicinskim napravama ${ }^{14}$.

Rincic Mlinaric i sur. objavili su istraživanje o citotoksičnom učinku iona $\mathrm{Ni}$ i Ti koji se oslobađaju iz zubnih implantata od legura na bazi titanija ${ }^{41}$. NiTi leguru ( $\mathrm{Ni}=50,4 \%$ i Ti $=49,6 \%$ ) izložili su umjetnoj slini te je došlo do korozije i oslobađanja metalnih iona, s time da se oslobodilo više iona nikla od iona titanija. Određivanje citotoksičnog učinka proveli su na staničnim linijama stanica jezika (CAL 27), jetre (Hep G2) i debelog crijeva (Caco-2) izlažući ih titanijevom dioksidu odnosno niklovom kloridu u odgovarajućim koncentracijama. Nije došlo do značajnog citotoksičnog učinka, a otkriveno je da niske koncentracije oslobođenih iona čak i potiču rast stanica. Međutim, pokazalo se da titanij i nikal međusobno imaju sinergistički učinak i tako mogu uzrokovati umjerenu do jaku citotoksičnost pri višim koncentracijama (minimalna ukupna konc. Iznosi 162 $\mu \mathrm{g} / \mathrm{L}$, s pojedinačnim koncentracijama od Ni 75,5 $\mu \mathrm{g} / \mathrm{L}$ i Ti 86,5 $\mu \mathrm{g} / \mathrm{L})$. Citotoksičan učinak i stvaranje slobodnih radikala bilo je jače za stanice jezika nego za stanice crijeva i jetre. Zanimljivost u ovom istraživanju jest da povećanje koncentracije iona titanija povećava stvaranje slobodnih radikala nešto više nego u slučaju povećanja koncentracije iona nikla ${ }^{41}$.

Izazivanje oksidacijskog stresa uslijed oslobađanja metalnih iona ispitali su Kovač i sur. Istraživanje su proveli na kvascu S. cerevisiae, divljeg tipa i dva mutanta $s$ nedostatkom antioksidativnih obrambenih enzima: $\Delta$ Sod1, kojem nedostaje superoksid dismutaza (SOD) i $\Delta \mathrm{Ctt1}$, kojem nedostaje katalaza (CAT). Uz citotoksičnost tako su mogli istražiti i doprinos nedostatka enzima, koji pružaju obrambeni mehanizam za uklanjanje reaktivnih vrsta kisika. Testirali su legure koje se najčešće koriste za izradu fiksnih ortodontskih naprava: nehrđajući čelik, $\mathrm{Ni}-\mathrm{Ti}, \beta$-titanij i Co-Cr. Sve legure, tj. njihovi metalni ioni, pri koncentraciji od $1000 \mu \mathrm{M}$ pokazale su citotoksičan učinak, dok su u slučaju mutiranih vrsta čak i koncentracije od $100 \mu \mathrm{M}$ bile citotoksične. Analizom unutarstanične oksidacije potvrđeno je da je citotoksičnost metalnih iona posljedica stvaranja ROS-a, te posljedičnog oksidacijskog stresa koji narušava staničnu redoks-homeostazu i oštećuje biomolekule (lipide, proteine i DNA). Prema ovom istraživanju, budući da samo visoke koncentracije oslobođenih metalnih iona iz ortodontskih naprava induciraju citotoksičnost i oksidativni stres, testirane legure mogu se smatrati nisko rizičnima. Međutim, veći se rizik može javiti u bolesnika s nedostatkom antioksidativnih obrambenih sustava ${ }^{22}$.

U modernoj se stomatologiji za površinsku obradu, tj. oblaganje zubnih implantata na bazi titanija koristi i mnoštvo nanomaterijala ${ }^{6}$. Ugrađivanjem metalnih nanočestica u biomaterijale poboljšavaju se svojstva biomaterijala. U stomatologiji se uz metalne nanočestice ( $\mathrm{Ag}, \mathrm{Ti}, \mathrm{Cu}, \mathrm{Au}, \mathrm{Zn}$ i $\mathrm{Zr}$ ) najviše koriste nanočestice titanijeva dioksida. Potencijalna opasnost nanočestica je u njihovom otpuštanju iz nanomaterijala dužim stajanjem ortodontskih sustava u ustima. Otpuštanjem nanočestica u slinu i njihovim ulaskom u krvotok može doći i do sustavnih učinaka. O njihovim toksičnim učincima još uvijek se vrlo malo zna ${ }^{46}$. Toksikološka procjena nanočestica stoga je od izuzetne važnosti. Tablica 1 sažeto prikazuje studije testiranja nanočestica, prvenstveno titanijeva dioksida na raznim modelnim organizmima te polučeni toksični učinak.

\section{ZAKLJUČCI}

Široka primjena materijala na osnovi titanija opravdava pitanja o upotrebi titanija kao sigurnog elementa. lako se smatra biokompatibilnim, u određenim su se studijama pokazali njegovi mogući negativni učinci na ljudsko zdravlje. Bitno je poznavati okolnosti u kojima bi titanij mogao izazvati oštećenja, bolesti ili reakciju preosjetljivosti te mehanizme nastanka takvih učinaka.

U stomatološkoj primjeni bitno je testiranje biokompatibilnosti materijala koji se primjenjuju. Najčešće se upotrebljavaju titanij i legure na bazi titanija te je bitno pronaći najprikladniju i najsigurniju leguru koja će biti što manje podložna koroziji i otpuštanju štetnih metalnih iona, koji bi dalje mogli pokrenuti brojne negativne učinke. Što je manja količina otpuštenih iona metala, to je manji rizik za zdravlje. Unatoč prikladnosti titanija koji ima minimalnu bioreaktivnost i minimalno odbacivanje tijela, treba voditi računa i o određe- 
Tablica 1. Prikaz istraživanja toksičnog djelovanja nanočestica titanija

\begin{tabular}{|c|c|c|c|c|}
\hline $\begin{array}{c}\text { Testirane } \\
\text { nanočestice }\end{array}$ & Modelni organizam & Toksičan učinak & Zaključci & $\begin{array}{c}\text { Autori } \\
\text { istraživanja }\end{array}$ \\
\hline $\begin{array}{l}\text { nano } \mathrm{TiO}_{2} \\
(\mathrm{ZnO} \text { i CuO) }\end{array}$ & kvasac S. cerevisiae & - Nije se pokazao & $\begin{array}{l}\text { Moguće je da stanična stijenka ometa } \\
\text { ulazak nanočestica u stanicu kvasca }\end{array}$ & $\begin{array}{l}\text { Kasemets i } \\
\text { sur. }^{32}\end{array}$ \\
\hline nano $\mathrm{TiO}_{2}$ & $\begin{array}{l}\text { alveolarne epitelne } \\
\text { stanice A549 i } \\
\text { limfoblastoidne TK6 } \\
\text { stanice }\end{array}$ & $\begin{array}{l}\text { - Neznatna citotoksičnost } \\
\text { - Oštećenje DNA } \\
\text { - Genotoksičnost }\end{array}$ & $\begin{array}{l}\text { Oštećenje DNA može nastati izravnom } \\
\text { interakcijom nanočestica s DNA ili } \\
\text { neizravnim putem, indukcijom } \\
\text { oksidacijskog stresa }\end{array}$ & $\begin{array}{l}\text { El Yamani i } \\
\text { sur. }^{47}\end{array}$ \\
\hline $\begin{array}{l}\text { nano } \mathrm{TiO}_{2} \\
\text { u usporedbi } \\
\text { sa mikro Ti } \\
\text { i mikro Ni-Ti }\end{array}$ & $\begin{array}{l}\text { stanice parodontalnog } \\
\text { ligamenta } \\
\text { (PDL-hTERT stanice) }\end{array}$ & $\begin{array}{l}\text { - } \mathrm{Nano}_{\mathrm{TiO}_{2}} \\
\text { imaju značajnije toksično } \\
\text { djelovanje i najveće } \\
\text { oštećenjem na DNA (mikro } \\
\text { Ni-Ti su toksičnije od mikro } \\
\mathrm{Ti} \text { ) }\end{array}$ & $\begin{array}{l}\text { Toksični učinci ovise o veličini čestica i } \\
\text { učinkovitosti staničnog unosa, ali i o } \\
\text { kemijskom sastavu legure }\end{array}$ & He i sur. ${ }^{37}$ \\
\hline $\begin{array}{l}\text { nano } \mathrm{TiO}_{2} \\
\text { mikro } \mathrm{TiO}_{2}\end{array}$ & $\begin{array}{l}\text { plućni fibroblasti } \\
\text { kineskog hrčka }\end{array}$ & $\begin{array}{l}\text { - Oštećenje DNA uslijed } \\
\text { stvaranja oksidativnog } \\
\text { stresa što smanjuje } \\
\text { održivost stanica }\end{array}$ & $\begin{array}{l}\text { Nanočestice u usporedbi s većim } \\
\text { česticama mogu potaknuti veće stvaranje } \\
\text { ROS-a, što dovodi do oksidacijskog stresa, } \\
\text { a dokazana je značajna razlika između } \\
\text { učinaka nanočestica i mikročestica } \\
\text { (nanočestice su toksičnije) }\end{array}$ & $\begin{array}{l}\text { Hamzeh i } \\
\text { Sunahara }^{48}\end{array}$ \\
\hline $\begin{array}{l}\text { nano } \mathrm{TiO}_{2} \\
\text { mikro } \mathrm{TiO}_{2}\end{array}$ & $\begin{array}{l}\text { izlaganje miševa } \\
\text { oralnim putem } \\
\text { analiza stanica mozga, } \\
\text { koštane srži, jetre, } \\
\text { debelog crijeva i testisa }\end{array}$ & $\begin{array}{l}\text { - Oštećenje DNA u koštanoj } \\
\text { srži i jetri } \\
\text { - Citotoksični učinci u } \\
\text { stanicama mozga, koštane } \\
\text { srži, debelog crijeva i testisa } \\
\text { - Apoptoza samo pri visokoj } \\
\text { dozi }\end{array}$ & $\begin{array}{l}\text { Suprotno očekivanjima, rezultati ove } \\
\text { studije pokazali su malu razliku između } \\
\text { učinaka nanočestica i mikročestica. Obje } \\
\text { dovode do navedenih toksičnih učinaka u } \\
\text { relativno jednakim mjerama }\end{array}$ & Sycheva i sur. ${ }^{58}$ \\
\hline $\begin{array}{l}\text { nano } \mathrm{TiC}, \\
\text { nano } \mathrm{TiCN} \\
\text { nano } \mathrm{TiO} \\
\text { nano } \mathrm{Ti}_{2} \mathrm{O}_{3} \\
\text { nano } \mathrm{TiO}_{2}, \\
\text { nano } \mathrm{TiN}^{\prime} \\
\text { nano } \mathrm{TiSO}_{2}\end{array}$ & $\begin{array}{l}\text { alveolarne HPAEpiC } \\
\text { stanice i stanice ždrijela } \\
\text { HPPC }\end{array}$ & $\begin{array}{l}\text { - Oksidativni stres } \\
\text { - Oštećenje DNA } \\
\text { - Upala } \\
\text { - Apoptoza }\end{array}$ & $\begin{array}{l}\text { Sve testirane nanočestice izazvale su na } \\
\text { objema staničnim linijama značajno } \\
\text { oštećenje DNA, oksidacijski stres, upalu i } \\
\text { apoptozu }\end{array}$ & Aydın i sur. ${ }^{49}$ \\
\hline $\begin{array}{l}\text { nano } \mathrm{TiO}_{2} \\
\text { (nano } \mathrm{ZnO} \text { ) }\end{array}$ & humani epitel HEp-2 & $\begin{array}{l}\text { - Modifikacija fosforilacije } \\
\text { tirozina } \\
\text { - Oštećenje DNA }\end{array}$ & $\begin{array}{l}\text { Dokazan je genotoksičan učinak, došlo je } \\
\text { do znatnog povećanja kromosomskih } \\
\text { mutacija pri najvišim koncentracijama, dok } \\
\text { citotoksičan učinak nije bio značajan }\end{array}$ & Osman i sur..$^{50}$ \\
\hline nano $\mathrm{TiO}_{2}$ & $\begin{array}{l}\text { kultivirani ljudski } \\
\text { limfociti }\end{array}$ & $\begin{array}{l}\text { - Blagi citotoksičan učinak } \\
\text { - Genotoksičnost s UVA } \\
\text { izloženosti se pojačava i } \\
\text { dovodi do apoptoze }\end{array}$ & $\begin{array}{l}\text { Nanočestice } \mathrm{TiO}_{2} \text { i UVA zračenje imaju } \\
\text { sinergijski učinak na održivost stanica. UVA } \\
\text { zračenje }\left(0,5 \mathrm{~J} / \mathrm{cm}^{2}\right) \text { pojačava genotoksične } \\
\text { učinke nanočestica TiO }{ }_{2} \text {, dolazi do brzog } \\
\text { stvaranja ROS-a i aktivacije kaspaze, što } \\
\text { značajno povećava apoptotsku staničnu } \\
\text { smrt }\end{array}$ & Kang i sur..$^{51}$ \\
\hline $\begin{array}{l}\text { nano } \mathrm{TiO}_{2} \\
\text { različitih } \\
\text { veličina: } \\
5 \mathrm{~nm} \\
15 \mathrm{~nm} \\
<100 \mathrm{~nm}\end{array}$ & $\begin{array}{l}\text { hibridne AL stanice } \\
\text { čovjeka i hrčka kojima } \\
\text { nedostaje } \\
\text { mitohondrijski DNA }\end{array}$ & $\begin{array}{l}\text { - Manje veličine nanočestica } \\
\text { induciraju povećano } \\
\text { stvaranje ROS-a i } \\
\text { genotoksičnost, dok veće } \\
\text { veličine jače stimuliraju } \\
\text { apoptotsku smrt stanica }\end{array}$ & $\begin{array}{l}\text { Mitohondrijska disfunkcija značajno } \\
\text { pridonosi toksičnosti izazvanoj } \\
\text { nanočesticama } \mathrm{TiO}_{2} \text { tijekom procesa } \\
\text { starenja, ovisno o veličini čestica. } \\
\text { Mitohondriji su potencijalan cilj toksičnog } \\
\text { odgovora nanočestica TiO2 koje uzrokuju } \\
\text { oštećenje funkcije mitohondrija i aktivaciju } \\
\text { kaspaze, dovodeći do apoptoze i povećane } \\
\text { citotoksičnosti }\end{array}$ & Wang i sur. ${ }^{52}$ \\
\hline
\end{tabular}




\begin{tabular}{|c|c|c|c|c|}
\hline $\begin{array}{c}\text { Testirane } \\
\text { nanočestice }\end{array}$ & Modelni organizam & Toksičan učinak & Zaključci & $\begin{array}{c}\text { Autori } \\
\text { istraživanja }\end{array}$ \\
\hline nano $\mathrm{TiO}_{2}$ & $\begin{array}{l}\text { ljudske amnionske } \\
\text { epitelne stanice WISH }\end{array}$ & $\begin{array}{l}\text { - Stvaranje ROS-a } \\
\text { - Aktivacija kaspaze, što } \\
\text { inducira staničnu smrt } \\
\text { - Oštećenje DNA }\end{array}$ & $\begin{array}{l}\text { Oksidacijski stres pokreće oštećenje } \\
\text { staničnih membrana i bioloških } \\
\text { makromolekula. Pri kritičnoj koncentraciji } \\
\text { od } 20 \mu \mathrm{g} / \mathrm{ml} \text { nano TiO }{ }_{2} \text { izazivaju oštećenje } \\
\text { DNA. Inhibicija razine antioksidacijskih } \\
\text { enzima nastupa pri nižim koncentracijama } \\
\text { od } 10 \mu \mathrm{g} / \mathrm{ml} \text {, dok pri višim koncentracijama } \\
\text { nano } \mathrm{TiO}_{2} \text { mogu negativno utjecati na } \\
\text { sposobnost popravljanja DNA }\end{array}$ & Saquib i sur. ${ }^{53}$ \\
\hline nano $\mathrm{TiO}_{2}$ & $\begin{array}{l}\text { ljudske neuronske } \\
\text { stanice SHSY5Y }\end{array}$ & $\begin{array}{l}\text { - Nije došlo do smanjene } \\
\text { održivosti neuronskih } \\
\text { stanica } \\
\text { - Genotoksičnost }\end{array}$ & $\begin{array}{l}\text { Učinci nano } \mathrm{TiO}_{2} \text { na ljudske neuronske } \\
\text { stanice nisu povezani sa stvaranjem ROS-a i } \\
\text { oksidacijskog oštećenja te ostaje upitan } \\
\text { mehanizam nastanka učinaka: internalizirane } \\
\text { nanočestice dovode do promjena u } \\
\text { staničnom ciklusu i genotoksičnosti }\end{array}$ & $\begin{array}{l}\text { Valdiglesias i } \\
\text { sur. }^{54}\end{array}$ \\
\hline nano $\mathrm{TiO}_{2}$ & $\begin{array}{l}\text { tri plućne stanične } \\
\text { linije: alveolarne } \\
\text { epitelne stanice, } \\
\text { endotelne stanice i } \\
\text { makrofagi }\end{array}$ & $\begin{array}{l}\text { - Neuravnoteženo redoks- } \\
\text { stanje i oksidativni stres } \\
\text { - Oštećenja staničnih } \\
\text { makromolekula: proteini, } \\
\text { lipidi i DNA }\end{array}$ & $\begin{array}{l}\text { ROS dovodi do oksidacijskog stresa koji } \\
\text { uzrokuje daljnje fiziološke učinke, } \\
\text { uključujući genotoksičnost, upalu i fibrozu, } \\
\text { aktivacijom staničnih signalnih putova }\end{array}$ & $\begin{array}{l}\text { Hanot-Roy i } \\
\text { sur. }^{55}\end{array}$ \\
\hline nano $\mathrm{TiO}_{2}$ & $\begin{array}{l}\text { ljudske alveolarne } \\
\text { epitelne stanice A549 i } \\
\text { bronhijalne stanice } \\
\text { BEAS-2B }\end{array}$ & $\begin{array}{l}\text { - Niska citotoksičnost } \\
\text { - Oštećenje DNA uslijed } \\
\text { oksidacijskog stresa samo } \\
\text { pri najvišoj konc. } \\
\text { - U BEAS-2B ne dolazi do } \\
\text { genotoksičnosti niti do } \\
\text { upale, već samo do blage } \\
\text { indukcije TNF- } \alpha\end{array}$ & $\begin{array}{l}\text { Različiti stanični odgovori objašnjavaju se } \\
\text { različitim interakcijama nano } \mathrm{TiO}_{2} \mathrm{~s} \\
\text { različitim vrstama stanica zbog njihovih } \\
\text { specifičnih karakteristika (veličina, naboj i } \\
\text { tendencija aglomeracije), zbog sastava } \\
\text { specifičnih medija za kulturu i zbog } \\
\text { različite stanične osjetljivosti }\end{array}$ & Ursini i sur. ${ }^{56}$ \\
\hline nano $\mathrm{TiO}_{2}$ & $\begin{array}{l}\text { ljudske alveolarne } \\
\text { epitelne stanice A549 i } \\
\text { bronhijalne stanice } \\
\text { BEAS-2B }\end{array}$ & $\begin{array}{l}\text { - Umjerena citotoksičnost } \\
\text { - Oštećenje DNA uslijed } \\
\text { oksidacijskog stresa }\end{array}$ & $\begin{array}{l}\text { Rezultati ukazuju na neizravnu } \\
\text { genotoksičnost nano } \mathrm{TiO}_{2} \text { i toksično } \\
\text { djelovanje na sustave popravka DNA u } \\
\text { objema testiranim staničnim linijama }\end{array}$ & $\begin{array}{l}\text { Biola-Clier i } \\
\text { sur. }^{57}\end{array}$ \\
\hline nano $\mathrm{TiO}_{2}$ & $\begin{array}{l}\text { mišje RAW } 264,7 \\
\text { stanice i supkronično } \\
\text { testiranje na albino } \\
\text { miševima oralnom } \\
\text { ekspozicijom tijekom } \\
90 \text { dana }\end{array}$ & $\begin{array}{l}\text { - Smanjena stanična } \\
\text { održivost pri višim dozama } \\
\text { - Prisutnost upalnih, } \\
\text { nekrotičnih, apoptotičnih } \\
\text { stanica u jetri i bubrezima } \\
\text { - Genotoksičnost }\end{array}$ & $\begin{array}{l}\text { Oštećenje DNA posljedica je stvaranja } \\
\text { ROS-a. Sposobnost nanočestica da izazovu } \\
\text { toksičnost na različitim ciljnim mjestima } \\
\text { organizma ovisi o njihovom ulasku i } \\
\text { prijenosu putem krvi. } \\
\text { Genotoksičnost dokazana i u uvjetima in } \\
\text { vitro i u in vivo }\end{array}$ & $\begin{array}{l}\text { Chakrabarti i } \\
\text { sur. }^{59}\end{array}$ \\
\hline nano $\mathrm{TiO}_{2}$ & $\begin{array}{l}\text { dugotrajna izloženost } \\
\text { na mužjacima štakora } \\
\text { tijekom } 90 \text { dana }\end{array}$ & $\begin{array}{l}\text { - Smanjenje tjelesne težine } \\
\text { - Splenomegalija } \\
\text { - Trombocitopenija, } \\
\text { leukopenija, neutrofilija i } \\
\text { eozinofilija } \\
\text { - Značajan porast razina IgG i } \\
\text { IgM, stimulacija CD4 + i CD8 } \\
\text { + stanica slezene } \\
\text { - Povišene razine LDH i } \\
\text { smanjena proliferacija } \\
\text { limfocita } \\
\text { - Značajno oštećenje DNA }\end{array}$ & $\begin{array}{l}\text { Zabilježen je značajan pad prirasta tjelesne } \\
\text { težine kod izloženih štakora jer } \mathrm{TiO}_{2} \text { može } \\
\text { poremetiti regulaciju crijevne funkcije i tako } \\
\text { smanjiti sposobnost apsorpcije hranjivih } \\
\text { tvari. U hematološkom testiranju značajna je } \\
\text { bila trombocitopenija, što ukazuje na } \\
\text { poremećaj zgrušavanja krvi. Histopatološka } \\
\text { analiza pokazala je infiltraciju neutrofila i } \\
\text { eozinofila u slezeni. Aktivacija eozinofila } \\
\text { nakon oralne primjene nastaje zbog } \\
\text { sposobnost } \mathrm{TiO}_{2} \text { da izazove alergijsku } \\
\text { reakciju tkiva. Kao posljedica neravnoteže u } \\
\text { imunološkom sustavu mogu nastati } \\
\text { sistemske ili autoimune reakcije. Dugotrajno } \\
\text { izlaganje } \mathrm{TiO}_{2} \text { dovodi do značajnog } \\
\text { smanjenja imunološkog odgovora tijela s } \\
\text { citotoksičnim i genotoksičnim djelovanjem. }\end{array}$ & Hasem i sur. ${ }^{60}$ \\
\hline
\end{tabular}




\begin{tabular}{|l|l|l|l|l|}
\hline $\begin{array}{c}\text { Testirane } \\
\text { nanočestice }\end{array}$ & Modelni organizam & \multicolumn{1}{|c|}{$\begin{array}{c}\text { Autori } \\
\text { Toksičan učinak }\end{array}$} & \multicolumn{1}{c|}{$\begin{array}{c}\text { Zaključci } \\
\text { istraživanja }\end{array}$} \\
\hline nano TiN & zametci ribe zebre & - Razvojna toksičnost & $\begin{array}{l}\text { Izloženost je dovela do skraćene duljine } \\
\text { tijela i smanjene pokretljivosti te je } \\
\text { utjecala na razvoj srca, jetre, živaca i } \\
\text { drugih organa, a dovela je i do povišene } \\
\text { razine ROS-a i smanjenog antioksidacijskog } \\
\text { kapaciteta, odnosno smanjene regulacije } \\
\text { ekspresije antioksidacijskih gena (nrf2, } \\
\text { gclc, gclm, ho-1 i nqo1) }\end{array}$ \\
\hline
\end{tabular}

nim okolnostima u kojima se narušava sigurnost titanija te o sinergističkom djelovanju s drugim metalima i tvarima. Stoga je važno i dalje provoditi procjenu biokompatibilnosti titanija kako bi se mogli odrediti uvjeti uporabe ovisno o vremenu izloženosti, vrsti upotrijebljene legure i zdravlju pacijenata.

\section{ZAHVALE}

Ovaj je rad sufinancirala Hrvatska zaklada za znanost, Slovensko-hrvatskim bilateralnim projektom (IPS-2020-01-7418) „Utvrđivanje pojavnosti, uzroka i štetnih učinaka oksidativnog stresa izazvanog uporabom fiksnih ortodontskih naprava".

Izjava o sukobu interesa: Autori izjavljuju kako ne postoji sukob interesa.

\section{LITERATURA}

1. Oshida Y. Introduction. In: Oshida $Y(e d)$. Bioscience and bioengineering of titanium materials. Amsterdam: Elsevier Science, 2007;1-8.

2. Wood MM, Warshaw EM. Hypersensitivity reactions to titanium: diagnosis and management. Dermatitis 2015; 26:7-25.

3. Shi H, Magaye R, Castranova V, Zhao J. Titanium dioxide nanoparticles: a review of current toxicological data. Part Fibre Toxicol [Internet]. 2013;10. [cited 2021 Feb 10]. Available from: https://doi.org/10.1186/1743-897710-15.

4. Fage SW, Muris J, Jakobsen SS, Thyssen JP. Titanium: a review on exposure, release, penetration, allergy, epidemiology, and clinical reactivity. Contact Derm 2016;74: 323-345.

5. Turzo K. Surface Aspects of Titanium Dental Implants. In: Sammour R (ed). Biotechnology - Molecular Studies and Novel Applications for Improved Quality of Human Life. London: IntechOpen, 2012.

6. Kim KT, Eo MY, Nguyen TTH, Kim SM. General review of titanium toxicity. Int J Implant Dent [Internet]. 2019;5. [cited 2021 Feb 16]. Available from: https://doi. org/10.1186/s40729-019-0162-x.

7. Velasco-Ortega E, Jos A, Cameán AM, Pato-Mourelo J, Segura-Egea JJ. In vitro evaluation of cytotoxicity and ge- notoxicity of a commercial titanium alloy for dental implantology. Mutat Res 2010;702:17-23.

8. Wang J, Liu K, Mo C, H Minchenko O, Zhang Y, Chen JR et al. Nano-titanium nitride causes developmental toxicity in zebrafish through oxidative stress. Drug Chem Toxicol 2020;9:1-10.

9. ADA Council on Scientific Affairs. Titanium applications in dentistry. J Am Dent Assoc 2003;134:347-349.

10. Mallineni SK, Nuvvula S, Matinlinna JP, Yiu CK, King NM. Biocompatibility of various dental materials in contemporary dentistry: a narrative insight. J Investig Clin Dent 2013;4:9-19.

11. Limberger KM, Westphalen GH, Menezes LM, MedinaSilva R. Cytotoxicity of orthodontic materials assessed by survival tests in Saccharomyces cerevisiae. Dent Mater [Internet]. 2011;27. [cited 2021 Feb 16]. Available from: https://doi.org/10.1016/j.dental.2011.01.001.

12. Gonçalves TS, de Menezes LM, Ribeiro LG, Lindholz CG, Medina-Silva R. Differences of cytotoxicity of orthodontic bands assessed by survival tests in Saccharomyces cerevisiae. Biomed Res Int [Internet]. 2014;2014. [cited 2021 Feb 16]. Available from: https://doi.org/10.1155/ 2014/143283.

13. Katić V, Špalj S. Testing methods of materials to be used in dental medicine. Med Flum 2014;50:268-278.

14. Dinca VC, Soare S, Barbalat A, Dinu CZ, Moldovan A, Stoica I et al. Nickel-titanium alloy: Cytotoxicity evaluation on microorganism culture. Appl Surf Sci 2006;252:46194624.

15. House K, Sernetz F, Dymock D, Sandy JR, Ireland AJ. Corrosion of orthodontic appliances--should we care? Am J Orthod Dentofacial Orthop 2008;133:584-592.

16. Cadosch D, Al-Mushaiqri MS, Gautschi OP, Meagher J, Simmen HP, Filgueira L. Biocorrosion and uptake of titanium by human osteoclasts. J Biomed Mater Res A 2010; 95:1004-1010.

17. Wysocki R, Tamás MJ. How Saccharomyces cerevisiae copes with toxic metals and metalloids. FEMS Microbiol Rev 2010;34:925-951.

18. Yang HC, Pon LA. Toxicity of metal ions used in dental alloys: a study in the yeast Saccharomyces cerevisiae. Drug Chem Toxicol 2003;26:75-85.

19. Brune D. Metal release from dental biomaterials. Biomaterials 1986;7:163-175.

20. Geurtsen W. Biocompatibility of dental casting alloys. Crit Rev Oral Biol Med 2002;13:71-84.

21. Li Y, Wong C, Xiong J, Hodgson P, Wen C. Cytotoxicity of titanium and titanium alloying elements. J Dent Res 2010;89:493-497. 
22. Kovač $\mathrm{V}$, Poljšak $\mathrm{B}$, Primožič J, Jamnik P. Are metal ions that make up orthodontic alloys cytotoxic, and do they induce oxidative stress in a yeast cell model? Int J Mol Sci [Internet]. 2020;21. [cited 2021 Mar 7]. Available from: https://doi.org/10.3390/ijms21217993.

23. Ciocan LT, Miculescu F, Miculescu M, Patrascu I. Biological reactions to dental implants. In: Turkyilmaz I (ed). Implant dentistry - a rapidly evolving practice. London: IntechOpen, 2011:505-530.

24. Temiz M, Dayi E, Saruhan N. Evaluation of blood titanium levels and total bone contact area of dental implants. BioMed Res Int [Internet]. 2018;4121639. [cited 2021 Mar 21]. Available from: https://doi. org/10.1155/2018/4121639.

25. Hafez HS, Selim EM, Kamel Eid FH, Tawfik WA, Al-Ashkar EA, Mostafa YA. Cytotoxicity, genotoxicity, and metal release in patients with fixed orthodontic appliances: a longitudinal in-vivo study. Am J Orthod Dentofacial Orthop 2011;140:298-308.

26. Karathia $H$, Vilaprinyo $E$, Sorribas A, Alves R. Saccharomyces cerevisiae as a model organism: a comparative study. PLoS One [Internet]. 2011;6. [cited 2021 Mar 21]. Available from: https://doi.org/10.1371/ journal.pone.0016015.

27. Botstein D, Fink GR. Yeast: an experimental organism for 21st Century biology. Genetics 2011;189:695-704.

28. Botstein D, Chervitz SA, Cherry JM. Yeast as a model organism. Science 1997; 277:1259-1260.

29. Kschischo M, Ramos J, Sychrová H. Membrane transport in yeast, an introduction. Adv Exp Med Biol 2016;892:110.

30. Nielsen J. Yeast systems biology: model organism and cell factory. Biotechnol J [Internet]. 2019;14. [cited 2021 Mar 21]. Available from: https://doi.org/10.1002/biot. 201800421.

31. Blaya MG, Marquezan M, Baptista-Silva A, Hirakata LM, Medina-Silva R. Cytotoxicity evaluation of orthodontic miniscrews. Saúde [Internet]. 2017;43. [cited 2021 Mar 24]. Available from: https://doi.org/10.5902/2236583422559.

32. Kasemets K, Ivask A, Dubourguier HC, Kahru A. Toxicity of nanoparticles of $\mathrm{ZnO}, \mathrm{CuO}$ and $\mathrm{TiO}_{2}$ to yeast Saccharomyces cerevisiae. Toxicol In Vitro 2009;23:1116-1122.

33. Miller-Fleming L, Giorgini F, Outeiro TF. Yeast as a model for studying human neurodegenerative disorders. Biotechnol J 2008;3:325-338.

34. Škara J, Nadalin S, Buretić-Tomljanović A, Blagović B. The study of neurodegenerative diseases on yeast model. Med Flum 2016;52:14-27.

35. Špalj S, Mlacović Zrinski M, Tudor Špalj V, Ivanković Buljan Z. In-vitro assessment of oxidative stress generated by orthodontic archwires. Am J Orthod Dentofacial Orthop 2012;141:583-589.

36. Ortiz AJ, Fernández E, Vicente A, Calvo JL, Ortiz C. Metallic ions released from stainless steel, nickel-free, and titanium orthodontic alloys: toxicity and DNA damage. Am J Orthod Dentofacial Orthop [Internet]. 2011;140. [cited 2021 Apr 6]. Available from: https://doi. org/10.1016/j.ajodo.2011.02.021.

37. He X, Hartlieb E, Rothmund L, Waschke J, Wu X, Van Landuyt $K L$ et al. Intracellular uptake and toxicity of three different Titanium particles. Dent Mater 2015;31:734-744.

38. Dias Corpa Tardelli J, Lima da Costa Valente M, Theodoro de Oliveira T, Cândido Dos Reis A. Influence of chemical composition on cell viability on titanium surfaces: A systematic review. J Prosthet Dent 2021;125:421-425.

39. Lee JJ, Song KY, Ahn SG, Choi JY, Seo JM, Park JM. Evaluation of effect of galvanic corrosion between nickel-chromium metal and titanium on ion release and cell toxicity. J Adv Prosthodont 2015;7:172-177.

40. Yonekura Y, Endo K, lijima M, Ohno H, Mizoguchi I. In vitro corrosion characteristics of commercially available orthodontic wires. Dent Mater J 2004;23:197-202.

41. Rinčić Mlinarić M, Durgo K, Katić V, Špalj S. Cytotoxicity and oxidative stress induced by nickel and titanium ions from dental alloys on cells of gastrointestinal tract. Toxicol Appl Pharmacol 2019;10:383.

42. de Morais LS, Serra GG, Albuquerque Palermo EF, Andrade LR, Müller CA, Meyers MA et al. Systemic levels of metallic ions released from orthodontic mini-implants. Am J Orthod Dentofacial Orthop 2009;135:522-531.

43. Noguti J, de Oliveira F, Peres RC, Renno AC, Ribeiro DA. The role of fluoride on the process of titanium corrosion in oral cavity. Biometals 2012;25:859-862.

44. Koike M, Fujii $\mathrm{H}$. The corrosion resistance of pure titanium in organic acids. Biomaterials 2001;22:2931-2936.

45. Reigosa M, Labarta V, Molinari G, Bernales D. Cytocompatibility, cytotoxicity and genotoxicity analysis of dental implants. J Phys Conf Ser [Internet]. 2007;90. [cited 2021 Apr 6]. Available from: https://iopscience.iop.org/ article/10.1088/1742-6596/90/1/012044.

46. Agnihotri R, Gaur S, Albin S. Nanometals in dentistry: applications and toxicological implications - a systematic review. Biol Trace Elem Res 2020;197:70-88.

47. El Yamani N, Collins AR, Rundén-Pran E, Fjellsb $\varnothing L M$, Shaposhnikov S, Zienolddiny $S$ et al. In vitro genotoxicity testing of four reference metal nanomaterials, titanium dioxide, zinc oxide, cerium oxide and silver: towards reliable hazard assessment. Mutagenesis 2017;32:117-126.

48. Hamzeh M, Sunahara GI. In vitro cytotoxicity and genotoxicity studies of titanium dioxide $\left(\mathrm{TiO}_{2}\right)$ nanoparticles in Chinese hamster lung fibroblast cells. Toxicol In Vitro 2013;27:864-873.

49. Aydın E, Türkez H, Hacımüftüoğlu F, Tatar A, Geyikoğlu F. Molecular genetic and biochemical responses in human airway epithelial cell cultures exposed to titanium nanoparticles in vitro. J Biomed Mater Res A 2017;105:20562064.

50. Osman IF, Baumgartner A, Cemeli E, Fletcher JN, Anderson D. Genotoxicity and cytotoxicity of zinc oxide and titanium dioxide in HEp-2 cells. Nanomedicine 2010;5: 1193-1203.

51. Kang SJ, Lee YJ, Kim BM, Choi YJ, Chung HW. Cytotoxicity and genotoxicity of titanium dioxide nanoparticles in UVA-irradiated normal peripheral blood lymphocytes. Drug Chem Toxicol 2011;34:277-284.

52. Wang Ju, Wang Ji, Liu Y, Nie Y, Si B, Wang T et al. Agingindependent and size-dependent genotoxic response induced by titanium dioxide nanoparticles in mammalian cells. J Environ Sci 2019;85:94-106.

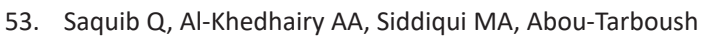
FM, Azam A, Musarrat J. Titanium dioxide nanoparticles induced cytotoxicity, oxidative stress and DNA damage in human amnion epithelial (WISH) cells. Toxicol In Vitro 2012;26:351-361.

54. Valdiglesias V, Costa C, Sharma V, Kiliç G, Pásaro E, Teixeira JP et al. Comparative study on effects of two differ- 
ent types of titanium dioxide nanoparticles on human neuronal cells. Food Chem Toxicol 2013;57:352-361.

55. Hanot-Roy M, Tubeuf E, Guilbert A, Bado-Nilles A, Vigneron $P$, Trouiller $B$ et al. Oxidative stress pathways in volved in cytotoxicity and genotoxicity of titanium dioxide $\left(\mathrm{TiO}_{2}\right)$ nanoparticles on cells constitutive of alveolo-capillary barrier in vitro. Toxicol In Vitro 2016;33:125-135.

56. Ursini CL, Cavallo D, Fresegna AM, Ciervo A, Maiello R, Tassone $P$ et al. Evaluation of cytotoxic, genotoxic and inflammatory response in human alveolar and bronchial epithelial cells exposed to titanium dioxide nanoparticles. J Appl Toxicol 2014;34:1209-1219.

57. Biola-Clier M, Beal D, Caillat S, Libert S, Armand L, Herlin-Boime $N$ et al. Comparison of the DNA damage response in BEAS-2B and A549 cells exposed to titanium dioxide nanoparticles. Mutagenesis 2017;32:161-172.
58. Sycheva LP, Zhurkov VS, lurchenko VV, Daugel-Dauge NO, Kovalenko MA, Krivtsova EK et al. Investigation of genotoxic and cytotoxic effects of micro- and nanosized titanium dioxide in six organs of mice in vivo. Mutat Res 2011;726:8-14.

59. Chakrabarti S, Goyary D, Karmakar S, Chattopadhyay P. Exploration of cytotoxic and genotoxic endpoints following sub-chronic oral exposure to titanium dioxide nanoparticles. Toxicol Ind Health 2019;35:577-592.

60. Hashem MM, Abo-El-Sooud K, Abd-Elhakim YM, Badr YA, El-Metwally AE, Bahy-El-Dien A. The long-term oral exposure to titanium dioxide impaired immune functions and triggered cytotoxic and genotoxic impacts in rats. J Trace Elem Med Biol [Internet]. 2020;60. [cited 2021 Apr 6]. Available from: https://doi.org/10.1016/j. jtemb.2020.126473 